\title{
Vitamin D-Dependent Calcium-Binding Proteins (CaBPs) in Human Fetuses: Comparative Distribution of 9K CaBP mRNA and 28K CaBP during Development
}

\author{
P. BRUN, J. M. DUPRET, C. PERRET, M. THOMASSET, AND H. MATHIEU
}

INSERM U.120, Le Vésinet, France

\begin{abstract}
The vitamin D-dependent calcium-binding protein (CaBP) cholecalcin or calbindin, has been used as a molecular marker of 1,25-dihydroxyvitamin $D_{3}$ action. Mammals possess two CaBPs: a 9,000 mol wt (9K CaBP) and a $28,000 \mathrm{~mol}$ wt (28K CaBP). The distinct localization of each protein in the rat has been previously described with the aid of specific radioimmunoassays developed for each CaBP. Antibodies raised against the rat $28 \mathrm{~K}$ CaBP can be used to detect this protein in a number of mammalian species including humans. In contrast, antibodies against rat $9 \mathrm{~K} \mathrm{CaBP}$ do not cross react with human $9 \mathrm{~K} \mathrm{CaBP}$, but human 9K CaBP mRNA can be analyzed using a cDNA probe for rat $9 \mathrm{~K}$ CaBP mRNA. Such a cross-hybridization between the rat cDNA probe and human CaBP mRNA was demonstrated by Northern analysis. We have documented the distribution and evolution of 28K CaBP and 9K CaBP mRNA in human tissues during fetal development from 14 to 32 wk of gestation. $28 \mathrm{~K} \mathrm{CaBP}$ was only present in kidney and cerebellum, and not detectable in duodenum. There was a 2 -fold increase of $28 \mathrm{~K}$ CaBP in the cerebellum between 14 and 24 wk of gestation. The $9 \mathrm{~K}$ CaBP mRNA was unevenly distributed in human fetal tissues. 9K CaBP mRNA was present in classical vitamin $D$ target tissues such as duodenum and placenta; high levels of 9K CaBP mRNA also were found in thymus and lung. These findings suggest a role for the hormone not only in the duodenum, placenta and kidney, but during the development of specific organs such as cerebellum, lung and thymus, and in agreement with many recent studies, point to a role of vitamin $D$ in cellular differentiation and growth. (Pediatr Res 21: 362-367, 1987)
\end{abstract}

\section{Abbreviations}

$1,25(\mathrm{OH})_{2} \mathrm{D}_{3}, 1,25$-dihydroxyvitamin $\mathrm{D}_{3}$

CaBP, calcium-binding protein

9K CaBP, 9,000 molecular weight calcium-binding protein

28K CaBP, 28,000 molecular weight calcium-binding protein

PGF $\alpha$, prostaglandin

DEPC, diethylpyrocarbonate

SDS, sodium dodecyl sulfate

Received July 12, 1986; accepted November 17, 1986.

Address all correspondence and request for reprints to Philippe Brun, INSERM U. 120, 44 Chemin de Ronde, 78110 Le Vesinet, France.

Supported by grants from the Centre National de la Recherche Scientifique (Biologie Moléculaire du Gène 033.107) and Unité d'Enseignement et de Recherche Xavier Bichat, Paris VII University.
The vitamin D-dependent CaBP, cholecalcin (1) or calbindin, is one of a group of intracellular proteins that bind calcium with an affinity constant $\mathrm{Ka}=10^{6} \mathrm{M}^{-1}(2,3)$. These proteins are the best known molecular markers of vitamin $\mathrm{D}$ action on target cells and have been characterized for a number of species (3). Birds have only one CaBP of 28,000 molecular weight, while two CaBPs have been described in mammals $(3,4)$. A small $9 \mathrm{~K}$ $\mathrm{CaBP}$ having two calcium-binding sites was first located in the absorptive cells of the duodenum (5) but is also found in the placenta $(6,7)$. A larger $28 \mathrm{~K}$ CaBP, similar to the chick $28 \mathrm{~K}$ CaBP (3), possesses four calcium-binding sites and is concentrated in the distal tubules of the kidney (8) and the Purkinje cells of cerebellum (9). Although their exact molecular functions remain unclear, $9 \mathrm{~K} \mathrm{CaBP}$ in the duodenum and the placenta as well as $28 \mathrm{~K} \mathrm{CaBP}$ in the kidney are probably involved in calcium transfer. $28 \mathrm{~K} \mathrm{CaBP}$ has been proposed as a marker of Purkinje cell differentiation and development of the cerebellum (10). Vitamin D-dependence of rat intestinal $9 \mathrm{~K} \mathrm{CaBP}$ gene expression was documented using either a cell free translation system (11) or a specific cDNA probe synthesized from rat mRNA coding for $9 \mathrm{~K} \mathrm{CaBP}(12)$. This specific cDNA probe hybridizes to a homogeneous 500-600 nucleotide rat duodenal mRNA species which directs the synthesis of $9 \mathrm{~K} \mathrm{CaBP}$, but not $28 \mathrm{~K} \mathrm{CaBP}$, in a cell-free system (1).

Human CaBP purified from cerebellum and kidney has the same molecular weight as chick or rat $28 \mathrm{~K} \mathrm{CaBP}$ and there is a cross-reactivity between antibodies raised to these proteins and human $28 \mathrm{~K}$ CaBP (13-15). $28 \mathrm{~K} \mathrm{CaBP}$ has been quantified in adult human postmortem tissues using a radioimmunoassay. The protein is found mainly in the kidney and cerebellum, but is also widely distributed throughout the nervous system (15).

As CaBPs are molecular markers of vitamin $\mathrm{D}$ action, we have studied these two markers during human fetal development. Antibodies raised to rat intestinal $9 \mathrm{~K} \mathrm{CaBP}$ do not cross-react with human $9 \mathrm{~K} \mathrm{CaBP}$, and thus, cannot be used to quantify it. However, human 9K CaBP mRNA can be analyzed using the ${ }^{32} \mathrm{P}$-labeled cDNA probe for rat $9 \mathrm{~K}$ CaBP mRNA. In the present study we have used this ${ }^{32} \mathrm{P}$-labeled cDNA probe to rat $9 \mathrm{~K} \mathrm{CaBP}$ and a radioimmunoassay for human $28 \mathrm{~K}$ CaBP to examine the distribution of both $9 \mathrm{~K} \mathrm{CaBP}$ mRNA and $28 \mathrm{~K} \mathrm{CaBP}$ in human fetal tissues and the changes in their concentration during fetal development from 14 to $32 \mathrm{wk}$ of gestation.

\section{MATERIALS AND METHODS}

Material. All radioisotopes were purchased from Amersham, Arlington Heights, IL. Nylon membranes were from New England Nuclear, and Oligo (dT) cellulose T7 from PL biochemicals. DNA polymerase, $T_{4}$ DNA ligase, baker's yeast tRNA, RNA 
molecular mass marker were obtained from Boehringer Mannheim, Mannheim, West Germany.

Preparation of tissues. Tissues were removed from 15 fetuses obtained after therapeutic abortions at 14 to $32 \mathrm{wk}$ of gestation: 21 trisomy $(n=6)$, Klinefeter's syndrome $(n=1)$, mucoviscidosis $(n=2)$, encephalocele $(n=1)$, maternal diseases $(n=5)$. All abortions were induced by $\mathrm{PGF} \alpha$ injection and samples were obtained between 30 min and $2 \mathrm{~h}$ postmortem. Each tissue was dissected out on ice, washed in cold sterile $0.9 \% \mathrm{NaCl}$, immediately frozen in liquid nitrogen and stored at $-80^{\circ} \mathrm{C}$. Samples were obtained from placenta, duodenum (freed from pancreatic fragments), lung, sternum, thymus, liver, kidney, cerebellum, and diaphragm.

Radioimmunoassay of $28 K \mathrm{KaBP}$. Prior to assay, each sample was homogenized with a Potter Elvehjem homogenizer in four volumes of $14 \mathrm{mM}$ Tris- $\mathrm{HCl} \mathrm{pH} \mathrm{7.4,120} \mathrm{mM} \mathrm{NaCl}$, and $3 \mathrm{mM}$ $\mathrm{KCl}$. A clear solution was obtained by centrifugation at 100,000 $\times g$ for $1 \mathrm{~h}$ and stored at $-20^{\circ} \mathrm{C}$. Aliquots were taken for total protein estimation using the one-step method of Bradford (16) and CaBP quantification by radioimmunoassay (13). The $28 \mathrm{~K}$ $\mathrm{CaBP}$ purified from rat kidney was used as the reference standard and to raise antibodies in rabbit. Serial dilutions of homogenates of human fetal samples produced curves parallel to the standard curve.

Preparation of cloned ${ }^{32} P$ cDNA probe. The cloned cDNA (pC109) inserted at the PstI site of chimeric plasmid of pBR322 was obtained from bacterial cells by alkali extraction following chloramphenicol amplification as previously described (12). After isolation by electroelution and purification on a DEAE cellulose (DE52) column, the cDNA fragments were ligated by $\mathrm{T}_{4}$ DNA ligase to increase the specific activity of the probe and then nick-translated in the presence of ${ }^{32} \mathrm{P}$ nucleotides (17). The labeled cDNA was isolated by chromatography on a Sephadex G50 microcolumn. The specific activity of the ${ }^{32} \mathrm{P}$ cDNA probe was about $2 \times 10^{8} \mathrm{cpm} / \mu \mathrm{g}$.

Extraction of total RNA and poly $A^{+} R N A$. Total RNA was extracted with phenol-chloroform according to Itoh et al. (18). Poly $\mathrm{A}^{+}$RNA was separated out by chromatography on oligo(dT)-cellulose $T_{7}$ as described by Aviv and Leder (19). All samples were stored at $-80^{\circ} \mathrm{C}$ in tubes which had been pretreated with DEPC $0.1 \%$ at $37^{\circ} \mathrm{C}$ overnight and autoclaved.

RNA Northern hybridization. The electrophoresis apparatus was treated with $0.2 \%$ DEPC before use. Poly $\mathrm{A}^{+}$RNA was denatured with formaldehyde (20) and electrophoresed on $1.3 \%$ horizontal agarose gels for $1 \mathrm{~h}$ at $100 \mathrm{~V}$ in $10 \mathrm{mM} \mathrm{NaH}_{2} \mathrm{PO}_{4}$, pH $6.5,3.3 \%(\mathrm{w} / \mathrm{w})$ formaldehyde, $0.3 \%$ DEPC, and then tranferred from the agarose gel to a nylon membrane using $20 \times \mathrm{SSC}$ (0.15 M NaCl, 0.015 M Na citrate, pH 7.0) buffer (21). RNA transfer was complete in 12-16 h. The filters were dried and baked for $2 \mathrm{~h}$ at $80^{\circ} \mathrm{C}$ before hybridization.

$R N A$ dot hybridization. Forty-five $\mu \mathrm{g}$ total RNA in $50 \mu \mathrm{l}$ of sterile water were incubated with $20 \mu \mathrm{l}$ of $20 \times \mathrm{SSC}$ and $30 \mu \mathrm{l}$ $37 \%$ formaldehyde $(\mathrm{w} / \mathrm{w})$ at $60^{\circ} \mathrm{C}$ for $15 \mathrm{~min}$. Eight hundred $\mu \mathrm{l}$ of $20 \times$ SSC were added for analysis. Serially diluted samples (with $20 \times$ SSC) were applied twice to a nylon filter using the Hybri Dot System (BRL, Bethesda, MD). The filters were dried under a lamp and baked for $2 \mathrm{~h}$ at $80^{\circ} \mathrm{C}$ before hybridization (22).

Hybridization assay. The filters were prehybridized in $50 \%$ (v/v) deionized formamide, $5 \times \mathrm{SSC}, 20 \mathrm{mM} \mathrm{NaH}_{2} \mathrm{PO}_{4}, \mathrm{pH} 7$, containing bovine serum albumin, Ficoll 400 and polyvinyl pyrrolidone (all at $0.2 \% \mathrm{w} / \mathrm{w}$ ), and $100 \mu \mathrm{g} / \mathrm{ml}$ of sonicated denatured salmon sperm DNA for at least $4 \mathrm{~h}$ at $42^{\circ} \mathrm{C}$. The hybridization buffer consisted of the above buffer to which was added $10 \%(\mathrm{w} / \mathrm{w})$ dextran sulfate and the nick-translated ${ }^{32} \mathrm{P}$ cDNA probe $(10 \mathrm{ng} \mathrm{cDNA} / \mathrm{ml})$. After hybridization $\left(16 \mathrm{~h}\right.$ at $42^{\circ}$ C), the filters were washed with four changes of $2 \times$ SSC, $0.1 \%$ SDS for $10 \mathrm{~min}$ each at room temperature. The filters were given two further washes with $2 \times \mathrm{SSC}, 0.1 \% \operatorname{SDS}$ at $50^{\circ} \mathrm{C}$ for $1 \mathrm{~h}$.
The blots were dried and autoradiographed at $-80^{\circ} \mathrm{C}$ using Kodak X-O-Mat film. The autoradiograms of the dot blot assay were analyzed by spectrodensitometry (Shimadzu Scientific Instruments, Columbia, MD). Previous experiments have demonstrated that, under DNA excess conditions, a linear relationship exists between the degree of hybridization and the RNA concentration when dotted total RNA does not exceed $10 \mu \mathrm{g}(23)$. Consequently, all measurements of human fetal $9 \mathrm{~K}$ CaBP mRNA were carried out from total RNA in the range 1.25-10 $\mu \mathrm{g} / \mathrm{dot}$ in the presence of DNA excess. Total RNA from rat duodenum was used as a standard. After hybridization with specific ${ }^{32} \mathrm{P}$ cDNA probe the amount of $9 \mathrm{~K} \mathrm{CaBP}$ mRNA in each RNA dot was quantified by spectrodensitometric analysis of the peak areas. Results were obtained from the spectrodensitometric analysis of the four total RNA concentrations dotted. Relative 9K CaBP mRNA levels were calculated from the slope of the hybridization curve and expressed as a ratio of standard rat 9K CaBP mRNA slope (arbitrary units).

Statistical analysis. All results were analyzed by variance analysis. When statistical significance was reached the groups were compared using Student Fisher's $t$ test.

\section{RESULTS}

Extraction of total RNA from human fetal tissues. The yield of the different experimental steps of phenol-chloroform extraction was different for each tissue (Table 1). Nucleic acid and total RNA concentrations were the highest in liver and kidney, an intermediate group included duodenum, lung, and placenta, whereas the lowest levels were obtained in cerebellum, thymus, and sternum. In all tissues the value of A260/A280 and A260/ A235 ratio, near 2, gives evidence of the quality of the extraction. Northern analysis of $9 K C a B P$ MRNA in human fetal tissues. Poly $\mathrm{A}^{+} \mathrm{RNA}$ preparations from placenta, lung, kidney, thymus, and liver of 20- to 23-wk-old fetuses electrophoresed under denaturing conditions on agarose gel, transferred to nylon membranes, and hybridized to the nick-translated ${ }^{32} \mathrm{P}$ cDNA showed that a single mRNA species was retained by the probe (Fig. 1). This mRNA contained approximately 500-600 bases and comigrated with the RNA from rat duodenum.

Distribution of $9 K$ CaBP mRNA in 20- to 23-wk-old human fetuses. Dot hybridization was used to quantify the $9 \mathrm{~K} \mathrm{CaBP}$ mRNA in the total RNA extracted from human fetal tissues. Spectrodensitometric analysis of the autoradiograms indicated that the $9 \mathrm{~K}$ CaBP mRNA was unevenly distributed in 20-wkold human fetuses (Fig. 2). The major tissues in which $9 \mathrm{~K} \mathrm{CaBP}$ gene was expressed were thymus, lung, duodenum, kidney, placenta, and cerebellum, with a higher $9 \mathrm{~K}$ CaBP mRNA concentration in the first two organs. There was a very low expression in liver, sternum, and diaphragm.

Statistical analysis of the results from six fetuses of approximately the same age (20-23 wk of gestation) showed three

Table 1. Yield of extraction of total nucleic acid and total RNA from human fetal tissues*

\begin{tabular}{lcccc}
\hline \multicolumn{1}{c}{ Tissues } & $\begin{array}{c}\text { Total nucleic acid } \\
(\mathrm{mg} / \mathrm{g} \text { tissue })\end{array}$ & $\begin{array}{c}\text { Total RNA } \\
(\mathrm{mg} / \mathrm{g} \text { tissue })\end{array}$ & $\mathrm{A}_{260} / \mathrm{A}_{280}$ & $\mathrm{~A}_{260} / \mathrm{A}_{235}$ \\
\hline Liver & $9.8 \pm 0.8$ & $5.1 \pm 0.5$ & $1.9 \pm 0.1$ & $1.9 \pm 0.2$ \\
Kidney & $6.0 \pm 0.5$ & $3.0 \pm 0.2$ & $1.9 \pm 0.1$ & $2.0 \pm 0.1$ \\
Duodenum & $5.1 \pm 0.4$ & $1.9 \pm 0.2$ & $2.1 \pm 0.1$ & $1.9 \pm 0.1$ \\
Lung & $5.0 \pm 0.5$ & $1.7 \pm 0.1$ & $1.9 \pm 0.1$ & $2.0 \pm 0.1$ \\
Placenta & $2.8 \pm 0.3$ & $1.6 \pm 0.2$ & $2.0 \pm 0.1$ & $2.1 \pm 0.1$ \\
Cerebellum & $2.3 \pm 0.3$ & $0.9 \pm 0.1$ & $1.9 \pm 0.1$ & $2.0 \pm 0.1$ \\
Thymus & $1.9 \pm 0.1$ & $0.8 \pm 0.1$ & $2.0 \pm 0.1$ & $2.4 \pm 0.2$ \\
Sternum & $1.8 \pm 0.1$ & $0.7 \pm 0.1$ & $1.9 \pm 0.2$ & $1.9 \pm 0.1$ \\
\hline
\end{tabular}

* The values are the mean \pm SEM of 15 different 14 - to 32 -wk-old fetuses. 


\section{PI D* D* Lg $\quad \mathrm{K} \quad \mathrm{D}^{*} \operatorname{Lg} \quad \mathrm{Li} \quad \mathrm{D}^{*} \mathrm{~T}$}

Fig. 1. Northern hybridization to ${ }^{32} \mathrm{P}$ cDNA probe of Poly $\mathrm{A}^{+}$RNA extracted from human fetal tissues at 20-23 wk of gestation. The autoradiograms resulting from four Northern hybridization assays $(1,2,3,4)$ of Poly $\mathrm{A}^{+} \mathrm{RNA}$ preparations $(10 \mu \mathrm{g})$ from placenta $(P l)$, lung $(L g)$, kidney $(k)$, liver $(L i)$, and thymus $(T)$ are shown. Total RNA extracted from rat duodenum $\left(D^{*}\right)$ was used as control. The size scale was determined by coelectrophoresis of ribosomal Escherichia coli RNA (5S, 16S, 23S).

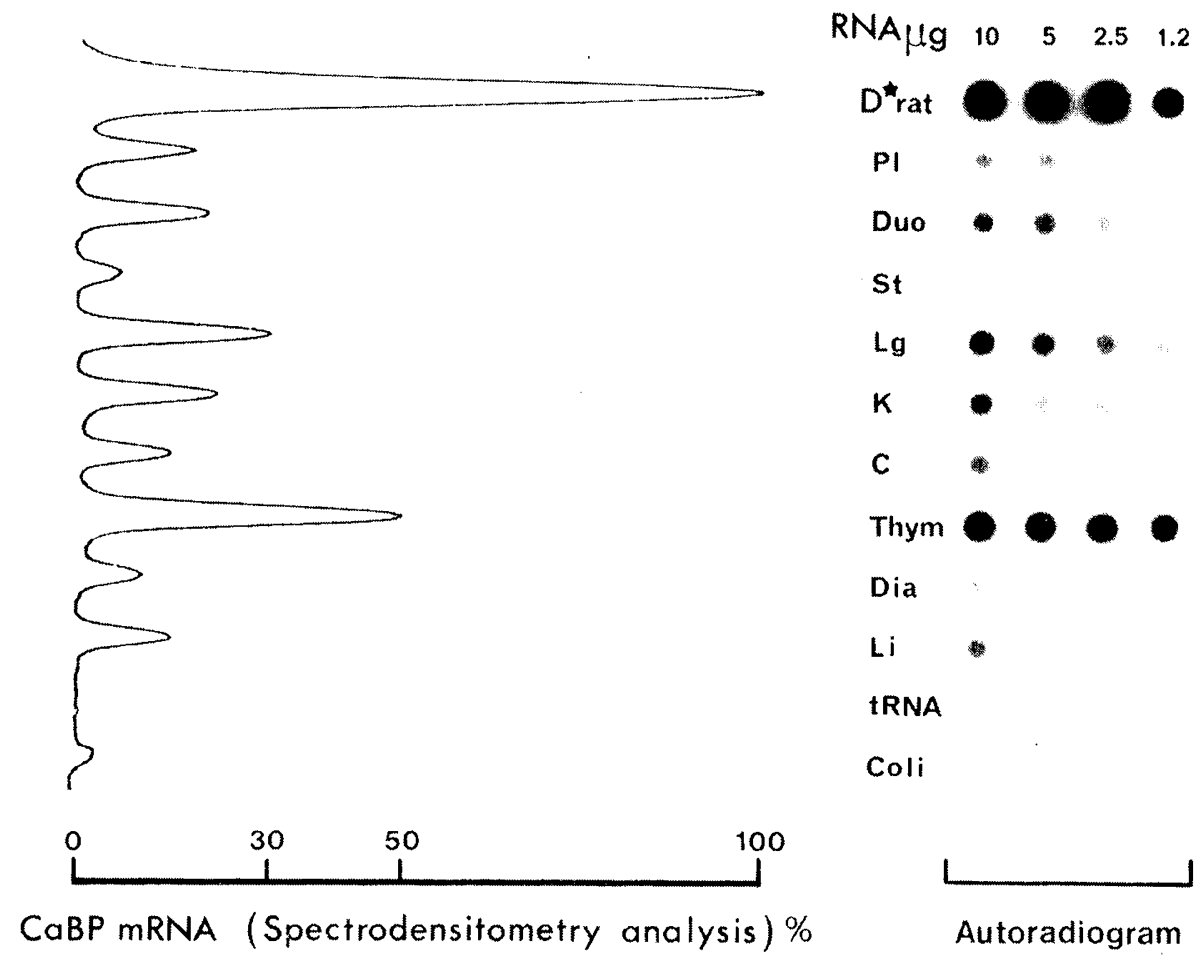

Fig. 2. Dot hybridization assay of $9 \mathrm{~K} \mathrm{CaBP}$ mRNA in a 20 -wk human fetus. Spectrodensitometric analysis of an autoradiogram resulting from eight scparate dot blot hybridization assays is shown. Total human fetal RNA $(10,5,2.5,1.25)$ from placenta $(P l)$, duodenum $(D u o)$, sternum $(S t)$, lung $(L g)$, kidney $(K)$, cerebellum $(C)$, thymus $(T h y m)$, diaphragm $(D i a)$, liver $(L i)$, and rat duodenum $\left(D^{*}\right.$ rat $)$ were dotted; tRNA from yeast $(t R N A)$ and RNA from Escherichia coli (Coli) were used as controls. The curve represents the scan of one of the four RNA dilutions analyzed.

significantly different groups of tissues. The highest levels of $9 \mathrm{~K}$ CaBP mRNA appeared in thymus, an intermediate group included lung and kidney, and a third group was composed of duodenum, cerebellum, liver, and placenta (Fig. 3).

Distribution of $28 \mathrm{~K} \mathrm{CaBP}$ in 20- to 23-wk-old fetuses. The tissue distribution of $28 \mathrm{~K} \mathrm{CaBP}$ is shown in Table 2. The cerebellum and kidney contained 1750 and $500 \mathrm{ng} / \mathrm{mg}$ protein, respectively, whereas the level was low in sternum $(30 \mathrm{ng} / \mathrm{mg}$ protein). $28 \mathrm{~K} \mathrm{CaBP}$ was undetectable in duodenum, liver, thymus, lung, and placenta. 


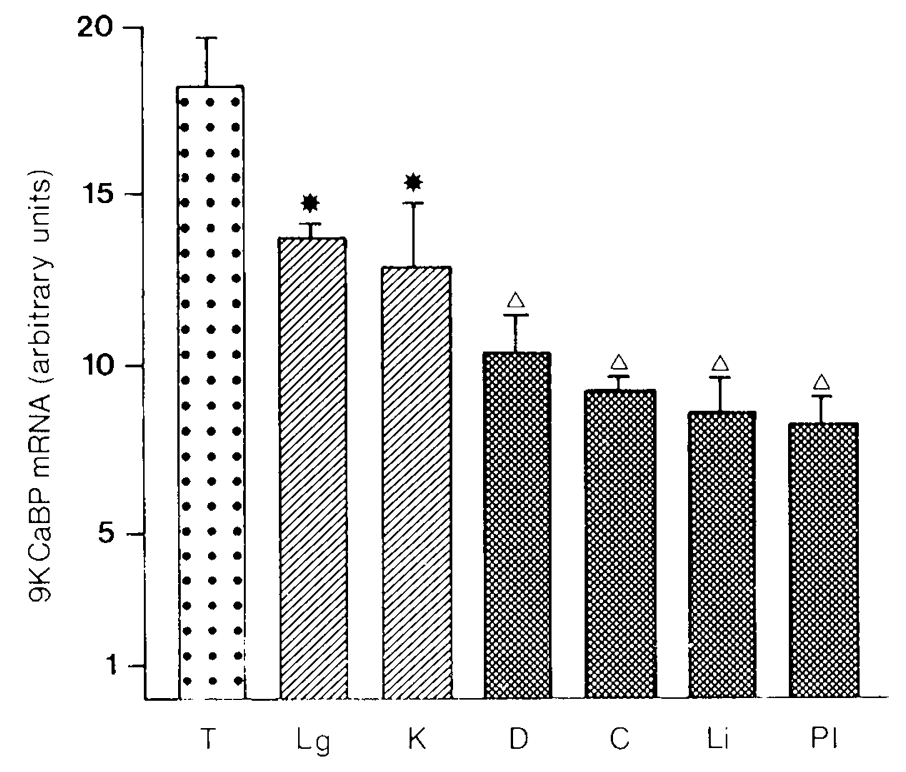

Fig. 3. Distribution of $9 \mathrm{~K}$ CaBP mRNA in human fetal tissues. $9 \mathrm{~K}$ CaBP mRNA concentration was analyzed by spectrodensitometry of dot hybridization assays of total RNA extracted from thymus $(T)$, lung $(L g)$, kidney $(K)$, duodenum $(D)$, cerebellum $(C)$, liver $(L i)$, and placenta $(P l)$. Each histogram is the mean of six separate assays corresponding to the tissues of 6-, 20-, to 23-wk-old fetuses, except for cerebellum (3). ${ }^{*} p<$ 0.001 as compared to thymus. $\Delta p<0.005$ as compared to lung and kidney.
Changes in $9 K \mathrm{CaBP} m R N A$ and $28 \mathrm{~K}$ CaBP during human fetal development. $9 \mathrm{~K} \mathrm{CaBP}$ gene expression was detectable as early as 14 wk of gestation in thymus, lung, duodenum, placenta, liver, kidney, and cerebellum (Fig. 4). There was no significant change in $9 \mathrm{~K} \mathrm{CaBP}$ mRNA levels in these organs from 14 to 32 wk of gestation (Fig. 4).

The $28 \mathrm{~K}$ CaBP concentration in the kidney remained unchanged between gestational wk 14 and 32 (Fig. 5). In contrast that of the cerebellum increased 2 -fold between 14 and $20 \mathrm{wk}$ of gestation (Fig. 5).

\section{DISCUSSION}

The number of human vitamin D-dependent CaBPs and their distribution reported in the adult is rather confused. Several studies have clearly demonstrated the presence of the large $28 \mathrm{~K}$

\begin{tabular}{cc} 
Table 2. Distribution of $28 \mathrm{~K}$ CaBP in human fetal tissues* \\
\hline Tissues & $\begin{array}{c}\text { 28K CaBP } \\
\text { (ng/mg soluble protein) }\end{array}$ \\
\hline Cerebellum & $1756 \pm 132$ \\
Kidney & $505 \pm 40$ \\
Sternum & $32 \pm 3$ \\
Duodenum & 0 \\
Liver & 0 \\
Lung & 0 \\
Thymus & 0 \\
Placenta & 0
\end{tabular}

*Values are means \pm SEM of five fetuses at 20 wk of gestation.
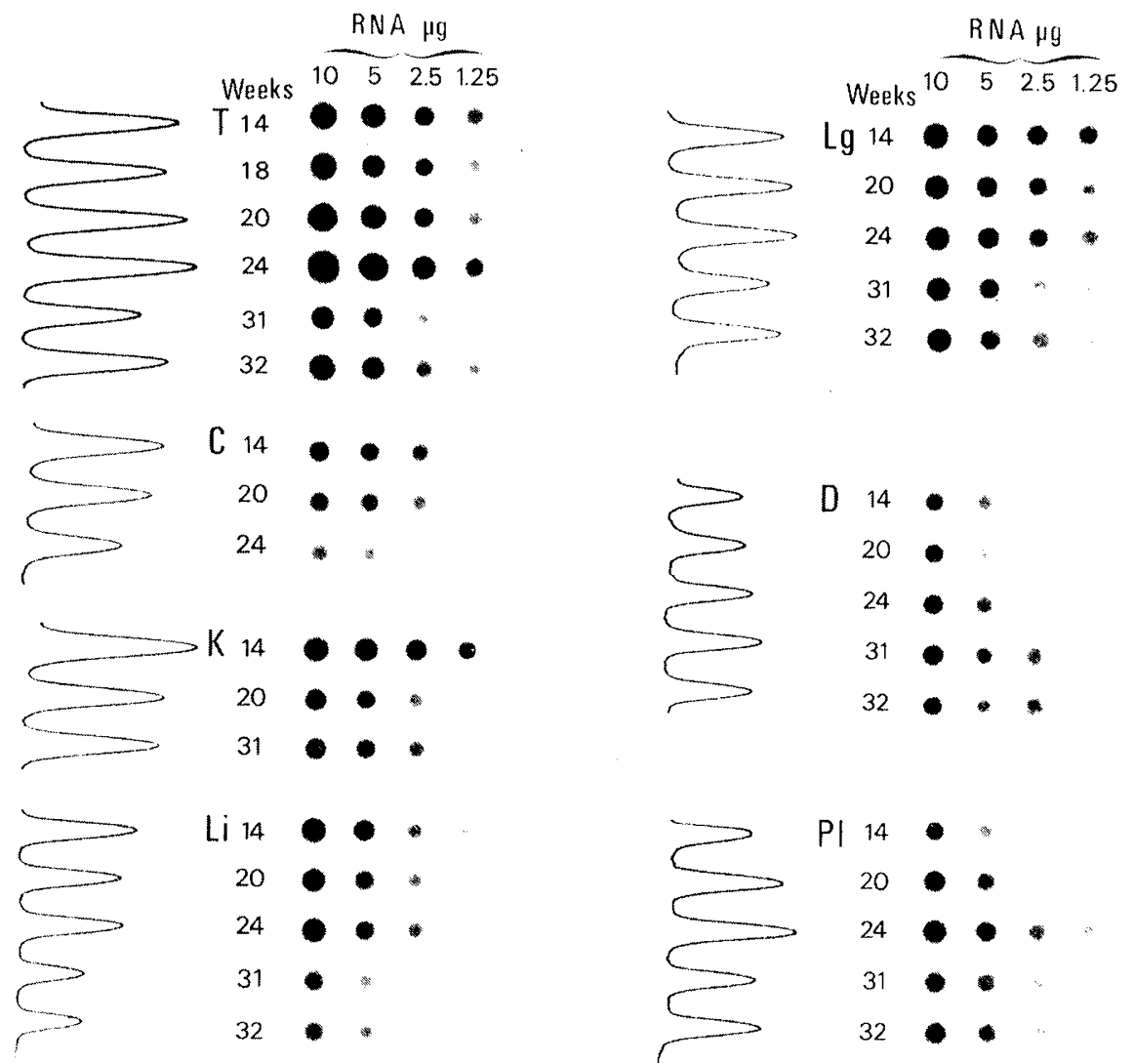

Fig. 4. Dot hybridization assay of $9 \mathrm{~K}$ CaBP mRNA in fetal tissues between 14 to 32 wk of gestation. $9 \mathrm{~K}$ CaBP mRNA concentration was analyzed by spectrodensitometry of dot hybridization assays of total RNA extracted from thymus $(T)$, cerebellum $(C)$, kidney $(K)$, liver $(L i)$, lung $(L g)$, duodenum $(D)$, and placenta $(P l)$. Tissues from different fetuses at $14,18,20,24,31$, and $32 \mathrm{wk}$ of gestation were analyzed. One autoradiogram $(b)$ for each tissue is shown and the curves $(a)$ represent the scan of one of the four dilutions assayed. 


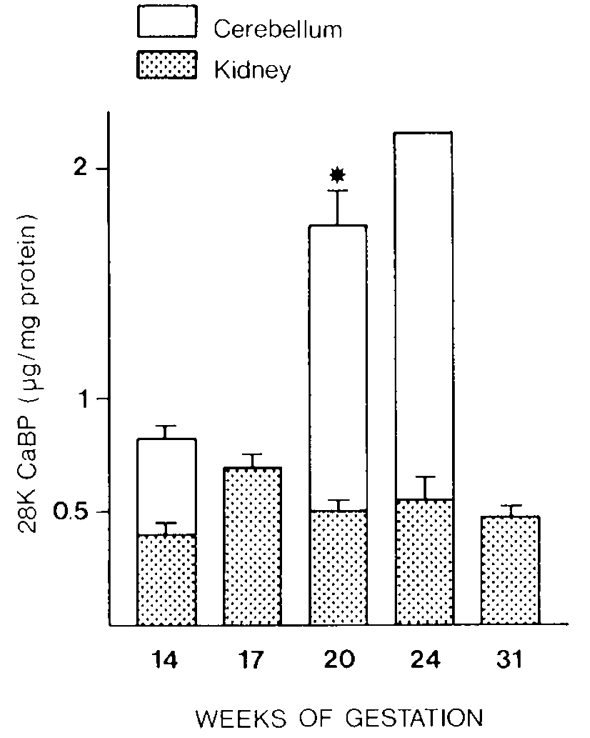

Fig. 5. Distribution of $28 \mathrm{~K} \mathrm{CaBP}$ in human fetal kidney and cerebellum between 14 and $31 \mathrm{wk}$ of gestation. Values are means \pm SEM of four fetuses for cerebellum except at $24 \mathrm{wk}$ of gestation (1) and three fetuses for kidney. ${ }^{*} p<0.05$ as compared to cerebellum at $14 \mathrm{wk}$ of gestation.

CaBP in the kidney $(14,15)$ and cerebellum (15) from adult necropsy obtained $12-24 \mathrm{~h}$ postmortem. Our findings of $28 \mathrm{~K}$ $\mathrm{CaBP}$ in kidney as early as $14 \mathrm{wk}$ of gestation are consistent with the report based on immunocytolocalization (24) in which it was shown that the $28 \mathrm{~K} \mathrm{CaBP}$ is present at $11 \mathrm{wk}$ of gestation in all medullary ducts and few distal tubules. We observed that the $28 \mathrm{~K} \mathrm{CaBP}$ level in the human fetal kidney did not increase from 14-31 wk of gestation. Immunochemical ontogenesis studies indicated that the distribution of human $28 \mathrm{~K} \mathrm{CaBP}$ changes as the kidney matures: the protein progressively disappears from the medullary ducts and its concentration increases in the distal tubules where it is found in adult (24). In the rat previous study has shown that the kidney content of $28 \mathrm{~K}$ CaBP increases abruptly 1 day before birth (4). In the present study, kidneys from the very late period of human gestation were not available for testing. The $28 \mathrm{~K} \mathrm{CaBP}$ appears very early in the cerebellum, at $14 \mathrm{wk}$, and seems to increase between 14 and $24 \mathrm{wk}$ of gestation. Although the vitamin D-dependence of cerebellum $28 \mathrm{~K} \mathrm{CaBP}$ has not been yet demonstrated (4), the appearance of $28 \mathrm{~K} \mathrm{CaBP}$ in the rat cerebellum is related to the Purkinje cell differentiation and the developmental increase of this protein reflects the overall maturation of Purkinje cells $(9,10)$. Such data suggest a possible role of the protein in the development of cerebellum. Further studies are clearly required on the immunocytolocalization of CaBP in human fetal cerebellum. The picture in the intestine is considerably less clear. Proteins of various sizes and immunological cross-reactivity have been reported (25). Our inability to detect $28 \mathrm{~K} \mathrm{CaBP}$ in human fetal duodenum is consistent with a previous study from our laboratory on adult human tissue (15).

Recent studies have shown that the rat cDNA probe recognizes human genomic DNA using Southern analysis. Hybridized rat and human genomic DNA have very similar restriction patterns when digested with the same enzymes (26). These data suggest that there is a single $9 \mathrm{~K} \mathrm{CaBP}$ gene in the rat and human. Northern analysis has shown that, in the rat, the cDNA probe hybridizes to a homogeneous $9 \mathrm{~K}$ CaBP mRNA species 500-600 nucleotides long and that there is no cross-hybridization between $9 \mathrm{~K}$ and $28 \mathrm{~K}$ CaBP mRNAs $(1,27)$. The present analysis shows that the cDNA probe recognizes only one 500-600 nucleotides species of mRNA in human fetal tissues which comigrates with the hybridized $28 \mathrm{~K} \mathrm{CaBP}$ mRNA from rat duodenum, indicating that there is a specific cross-hybridization between the rat cDNA probe and human fetal 9K CaBP mRNA.

9K CaBP mRNA is widely and unevenly distributed in human fetal tissues. The presence of $9 \mathrm{~K}$ CaBP mRNA in human fetal kidney and cerebellum correlates with that observed in the growing rats in the same organs (1). Such results in cerebellum and kidney should be confirmed by investigation in rat fetuses. The presence of $9 \mathrm{~K}$ CaBP mRNA in human fetal duodenum and placenta also correlates with that observed in the rats (7). Only a single report has described the isolation of a small 10000 Mr CaBP from human jejunum (28). The presence of a human mRNA which hybridizes to the specific cDNA encoding rat $9 \mathrm{~K}$ CaBP mRNA is in agreement with the latter study and demonstrates that only $9 \mathrm{~K}$ CaBP gene is expressed in fetal human duodenum. During rat fetal development, $9 \mathrm{~K} \mathrm{CaBP}$ appears in duodenum at the end of gestation (19-20 days) and the concentration increases dramatically after birth (4). $9 \mathrm{~K} \mathrm{CaBP}$ mRNA levels in the rat placenta represent 7 and $50 \%$ of rat duodenum CaBP mRNA at day 15 and 21 of gestation, respectively (29). The present study included no material from the late period of human gestation, precluding the detection of such an increase.

The presence of high concentrations of $9 \mathrm{~K} \mathrm{CaBP} \mathrm{mRNA}$ in the thymus and lung of human fetuses revealed by the present study is somewhat unexpected. Such a level of $9 \mathrm{~K}$ CaBP gene expression as that observed in these two tissues, which are not involved in calcium transfer, suggests that $\mathrm{CaBP}$ may be implicated in the modulation of differentiation and development. Many recent studies point to the role of vitamin $\mathrm{D}$ in cellular differentiation; e.g. the induction of bone marrow stem cells differentiation and maturation especially in monocyte-macrophage cell lines (30). There is also evidence that $1,25(\mathrm{OH})_{2} \mathrm{D}_{3}$ acts as an immunoregulatory hormone by inhibiting lymphocyte interleukin 2 production and the proliferation of activated lymphocytes (31). All those actions occur via a receptor-mediated mechanism and involve physiological doses of the hormone. The $1,25(\mathrm{OH})_{2} \mathrm{D}_{3}$ receptors in rat thymus gland are only found in the mitotically active medullary zone (32). In this organ, $1,25(\mathrm{OH})_{2} \mathrm{D}_{3}$ inhibits the proliferation of active thymoblasts and induces their differentiation (33). Little is known of the vitamin $\mathrm{D}$ action in the lung. Rachitic rats show a distensibility of the lungs which results from disturbed development of alveolae and connective tissues (34). Maturation of the lung is closely linked to the appearance and proliferation of pulmonary macrophages. These cells, which are derived from the monocyte-cell line, have $1,25(\mathrm{OH})_{2} \mathrm{D}_{3}$ receptors and are activated by the hormone (35). Immunohistological studies will be necessary before the role of $9 \mathrm{~K} \mathrm{CaBP}$ in the development of both thymus and lung can be described in more details.

The presence of the two vitamin D-dependent CaBPs in the human fetus indicates that this species follows the general pattern of calcium-binding protein distribution found in the rat, specially in classical vitamin D target tissues. Moreover, the demonstration of CaBPs gene expression in human fetal tissues which are not directly involved in calcium homeostasis, such as thymus, lung, and cerebellum, adds to the growing body of evidence for a role of vitamin $D$ in the differentiation and growth at specific stage of development.

Acknowledgments. The authors are grateful to Dr. Y. Dumez, Dr. P. Blot, and Dr. F. Müller who obtained the fetal specimens used in this study and to M. Eb and N. Gouhier for their expert technical assistance. We are also grateful to L. Castera, M. Courat, and Dr. O. Parkes for their help in the preparation of the manuscript.

\section{REFERENCES}

1. Perret C, Desplan C, Brehier A, Thomasset M 1985 Characterization of rat $9 \mathrm{~K}$ cholecalcin (CaBP) messenger RNA using a complementary DNA: absence of homology with $28 \mathrm{~K}$ cholecalcin mRNA. Eur J Biochem 148:61-66 
2. Kretsinger RH 1976 Calcium-binding proteins. Ann Rev Biochem 45:239_ 266

3. Wasserman RH, Fullmer CS 1982 Vitamin D-Induced Calcium-binding protein. In: Cheung WY (ed) Calcium and Cell Function. Academic Press, New York, pp 175-216

4. Thomasset M, Parkes CO, Cuisinier-Gleizes P 1982 Rat calcium-binding proteins: distribution, development and vitamin D dependence. Am J Phys 243:E483-E488

5. Marche P, Le Guern C, Cassier P 1979 Immunocytochemical localization of a calcium-binding protein in the rat duodenum. Cell Tissue Res 197:69-77

6. Bruns ME, Fausto A, Avioli LV 1978 Placenta calcium-binding protein in rats, apparent identity with vitamin D-dependent calcium-binding protein from rat intestine. J Biol Chem 253:3186-3190

7. Warembourg M, Perret C, Thomasset M 1986 Distribution of vitamin Ddependent calcium-binding protein mRNA in rat placenta and duodenum. Endocrinology 119:176-184

8. Schreiner DS, Jande SS, Parkes CO, Lawson DEM, Thomasset M 1983 Immunocytochemical demonstration of two vitamin D-dependent calciumbinding proteins in mammalian kidney. Acta Anat 117:1-14

9. Legrand C, Thomasset M, Parkes CO, Clavel MC, Rabié A 1983 Calciumbinding protein in the developing rat cerebellum: an immunocytochemical study. Cell Tissue Res 233:385-402

10. Thomasset M, Rabié A, Parkes CO, Desplan C, Henin D, Cuisinier-Gleizes P 1984 Vitamin D-dependent calcium-binding protein in the cerebellum: a marker of the Purkinje cell development. Dev Pharmacol Ther 7:6-10

11. Desplan C, Brehier A, Perret C, Thomasset M 1983 Rat duodenal calciumbinding protein messenger RNA: induction by 1,25 -dihydroxyvitamin $\mathrm{D}_{3} . \mathrm{J}$ Steroid Biochem 19:1577-1582

12. Desplan C, Thomasset M, Moukhtar M 1983 Synthesis, molecular cloning and restriction analysis of DNA complementary to vitamin D-dependent calcium-binding protein mRNA from rat duodenum. J Biol Chem 258:27622765

13. Intrator S, Elion J, Thomasset M, Brehier A 1985 Purification, immunological and biochemical characterization of rat $28 \mathrm{kDa}$ cholecalcin (cholecalciferol induced calcium-binding protein). Biochem J 231:89-95

14. Morrissey RL, Rath DF 1974 Purification of human renal calcium-binding protein from necropsy specimens. Proc Soc Exp Biol Med 145:699-703

15. Parkes CO, Thomasset M, Baimbridge KG, Henin D 1984 Tissue distribution of human calcium-binding protein $\left(28,000 \mathrm{~g} \mathrm{~mol}^{-1}\right)$. Eur J Clin Invest 14:181-183

16. Bradford MM 1976 A rapid and sensitive method for quantitation of microgram quantities of protein using the principle of protein dye binding. Anal Biochem 72:248-254

17. Rigby PMJ, Dickmann H, Rhodes C, Berg P 1977 Labeling deoxyribonucleic acid to high specific activity in vitro by nick-translation with DNA polymerase I. J Mol Biol 113:237-251

18. Itoh N, Nose K, Okamoto M 1979 Purification and characterisation of proinsulin mRNA from rat B cell tumor. Eur J Biochem 97:1-9

19. Aviv M, Leder P 1972 Purification of biologically active globin messenger RNA by chromatography on oligothymidylic acid cellulose. Proc Natl Acad Sci USA 69:1408-1412
20. Lehrach H, Diamond D, Woazney JM, Boedtker H 1977 RNA molecular weight determination by gel electrophoresis under denaturing conditions, a critical reexamination. Biochemistry 16:4743-4746

21. Thomas PS 1980 Hybridization of denatured RNA and small DNA fragments transferred to nitrocellulose. Proc Natl Acad Sci USA 77:5201-5205

22. White $A B$, Bancroft FC 1982 Cytoplasmic dot hybridization: simple analysis of relative mRNA levels in multiple small cell or tissue samples. J Biol Chem 257:8569-8572

23. Perret C, Desplan C, Thomasset M 1985 Cholecalcin (a 9-kDa cholecalciferolinduced calcium-binding protein) messenger RNA: distribution and induction by calcitriol in the rat digestive tract. Eur J Biochem 150:211-217

24. Mounier F, Hinglais N, Brehier A, Thomasset M, Lacoste M, Sichs M, Gübler MC 1986 Ontogenis of $28 \mathrm{kDa}$ vitamin D induced calcium-binding protein in human kidney. Kidney Int 31:121-129

25. Davie M 1981 Calcium-ion-binding activity in human small intestinal mucosal cytosol. Purification of two proteins and interrelationship of calcium-binding fractions. Biochem J 197:55-60

26. Desplan C, Auffray C, Thomasset M 1984 Isolation and characterisation of genomic clones from mouse and human libraries encoding $9 \mathrm{~K}$ intestinal vitamin D-dependent calcium-binding protein. In: Cohn DV (ed) Endocrine Control of Bone and Calcium Metabolism. Elsevier Science Publishers, New York, pp 327-330

27. Thomasset M, Desplan C, Parkes CO 1983 Rat vitamin D-dependent calciumbinding proteins specificity of mRNAs coding for the $7500 \mathrm{Mr}$ protcin from duodenum and the $28,000 \mathrm{Mr}$ protein from kidney and cerebellum. Eur J Biochem 129:519-524

28. Staun M 1985 The crypt-villus distribution of calcium-binding protein in biopsy of human jejunum measured by an enzyme-linked immunoabsorbent assay. In: Norman AW, Schaefer K, Grigoleit HG, Herrath DV (eds) Vitamin D: A Chemical, Biochemical and Clinical Update. De Gruyter, Berlin, pp 383-384

29. De Maintenant F, Perret C, Brun P, Thomasset M 1985 Expression of cholecalcin ( $9000 \mathrm{Mw}$ cholecalciferol-induced $\mathrm{CaBP}$ ) gene in rat duodenum and placenta during gestation. In: Norman AW, Schaefer K, Grigoleit HG Herrath DV (eds) Vitamin D: A Chemical, Biochemical and Clinical Update. De Gruyter, Berlin, pp. 355-356

30. Manolagas SC, Deftos LJ 1984 The vitamin D endocrine system and the hematolymphoietic tissue. Ann Intern Med 100:144-146

31. Tsoukas CD, Provvedini DM, Manolagas SC 1984 1-25 dihydroxyvitamin $\mathrm{D}_{3}$ : a novel immunoregulatory hormone. Science 224:1438-1439

32. Provvedini DM, Deftos LJ, Manolagas SC 1984 1-25 Dihydroxyvitamin $\mathrm{D}_{3}$ receptors in a subset of mitotically active lymphocytes from rat thymus. Biochem Biophys Res Commun 121:277-283

33. Ravid A, Koren R, Novogrodsky A, Liberman VA 1984 1-25 dihydroxyvitamin $\mathrm{D}_{3}$ inhibits selectively the mitogenic stimulation of mouse medullary thymocytes. Biochem Biophys Res Commun 123:163-169

34. Gaultier CL, Harf A, Balmain N, Cuisinier-Gleizes P, Mathieu H 1984 Lung mechanism in rachitic rats. Am Rev Respir Dis 130:1108-1110

35. Jacobs RF, Christopher BW, Palmer Springmeyer SC, Henderson WR, Glover DM, Kessler DL, Murphy JF, Hughes JP, Van Belle G, Chi Y, Hodson WA 1985 Factor related to the appearance of alveolar macrophages in the developing lung. Am Rev Respir Dis 131:548-553 